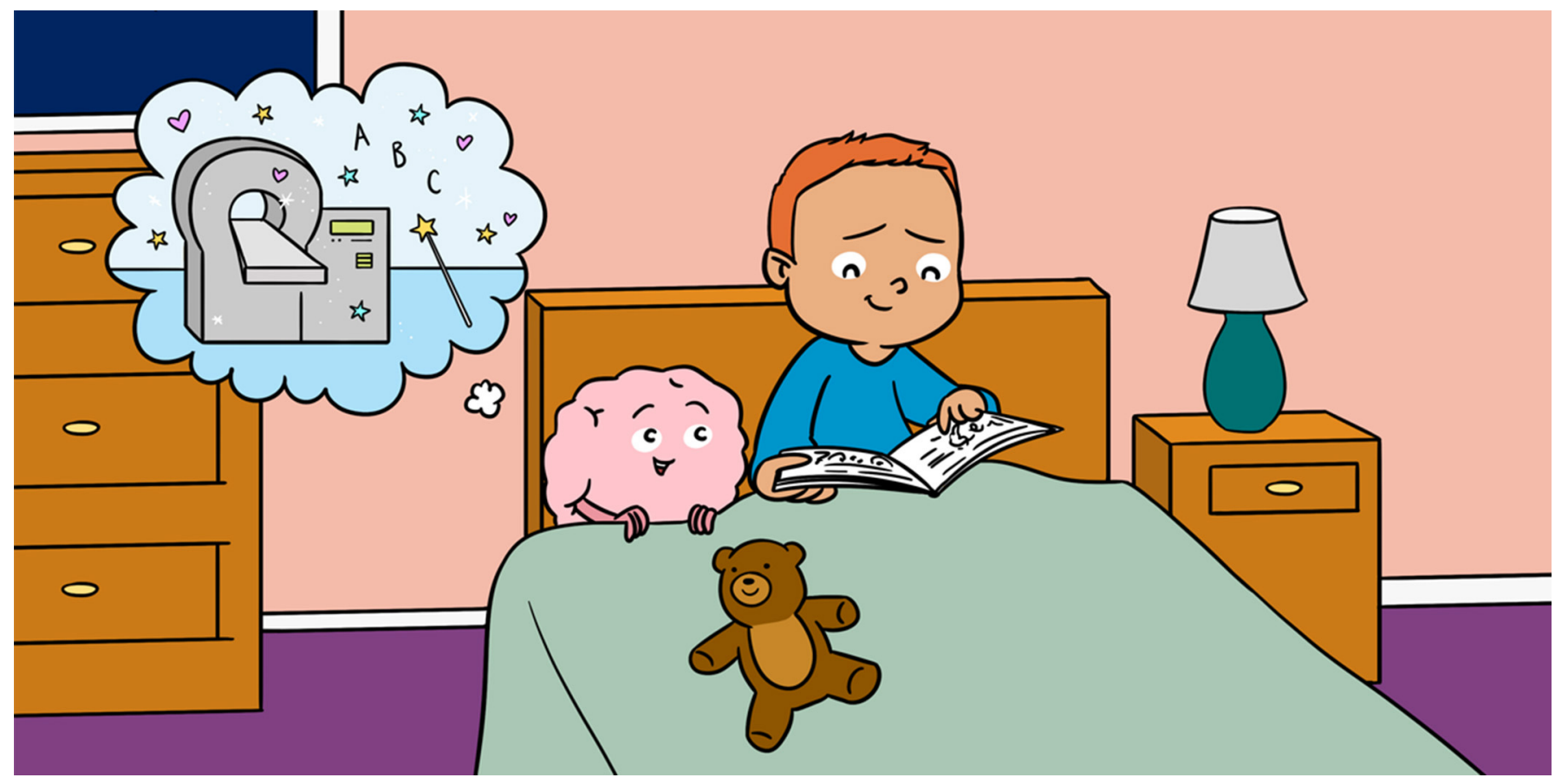

\title{
THE MAGICAL ART OF MAGNETIC RESONANCE IMAGING TO STUDY THE READING BRAIN
}

\section{Nora Maria Raschle ${ }^{1 *}$, Réka Borbás ${ }^{1}$, Carolyn King ${ }^{2}$ and Nadine Gaab ${ }^{2,3}$ \\ ${ }^{1}$ Jacobs Center for Productive Youth Development, University of Zurich, Zurich, Switzerland \\ ${ }^{2}$ Laboratories of Cognitive Neuroscience, Boston Children's Hospital, Harvard Medical School, Boston, MA, United States \\ ${ }^{3}$ Harvard Graduate School of Education, Cambridge, MA, United States}

\section{YOUNG REVIEWERS:}

CASCADIA

ELEMENTARY

AGES: 8-9
In the Harry Potter book series, the legilimency spell was used to access and read another person's mind. However, magic always come with a great responsibility and should only be used with caution. Similarly, magnetic resonance imaging (or MRI) is a powerful tool that lets us take detailed images of different parts of the body, including the brain. But MRI should also only be used and interpreted with caution. MRI gives us an opportunity to look at different parts of the body from the outside. Some muggles (non-wizards) use MRI to study the secrets of the human brain. While it cannot be used to read someone's mind, it can tell us how a brain looks, works, grows, and learns. For example, MRI can help us understand how the brain learns to read and what may be different in children who struggle with learning to read.

Do you like to read? Have you read the Harry Potter books? Reading is an ability that is learned through instruction (e.g., a teacher or parent 
Figure 1

Step-by-step, we learn to read. There are several stages that we may take to become fluent readers. Learning to read starts from the time a baby starts growing and continues throughout schooling and until young adulthood (Illustrations: N. M. Raschle; the top part of this graphic is adapted from Chall [1]).

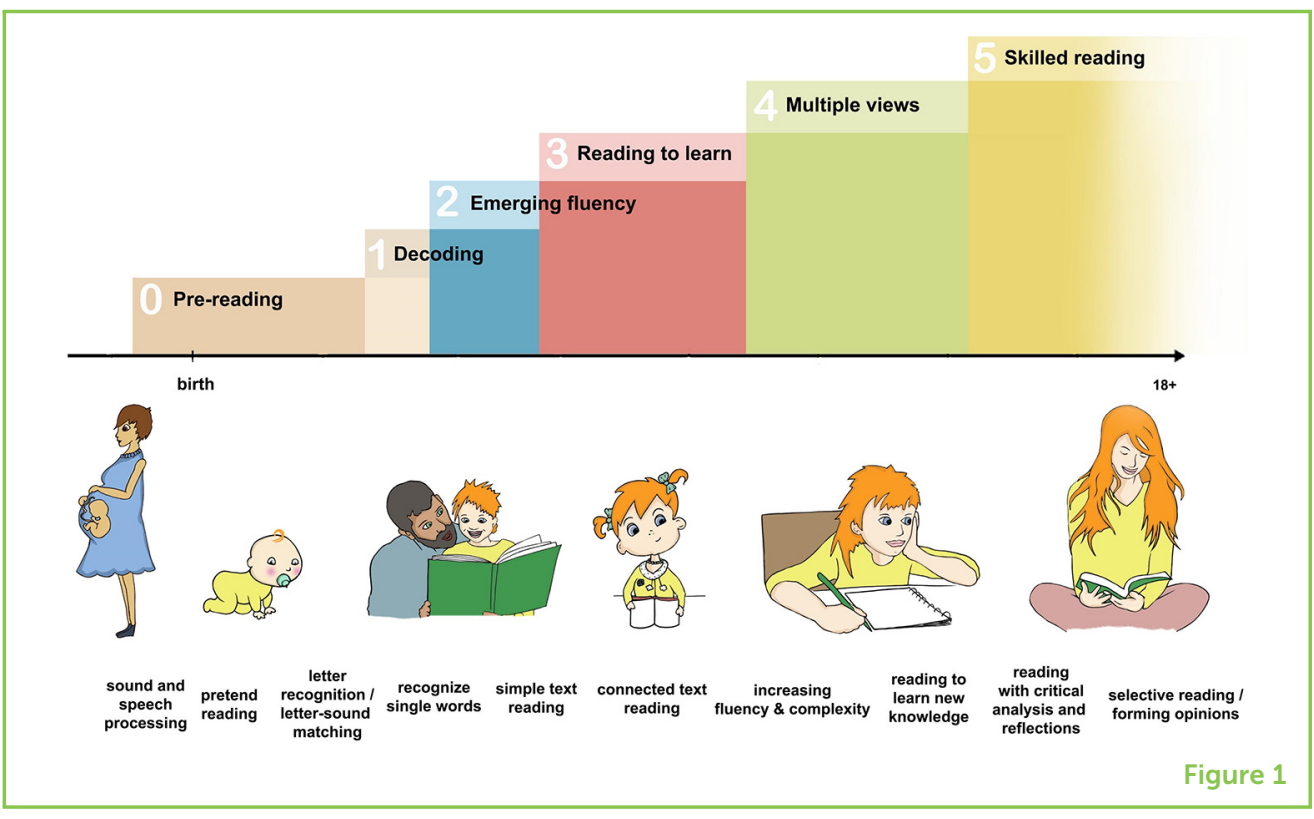

teaching you) and needs much practice at home or in school. Many different things help us become great readers. As we grow up, we have many experiences, and our bodies, our thinking, our feelings, and the environment around us are always changing. Early in life, we learn the easier skills, like understanding the meaning of certain sounds, recognizing faces, or walking. In fact, learning starts even before we are born! As we grow, we learn more complex skills, like speaking words and sentences, reading, and how to interact with others. Learning new skills goes hand-in-hand with the development of the brain. But many different things can affect how we develop, including changes in our environments, our learning experiences, or even our DNA, which is the biological information that our parents pass on to us.

This is also true for reading. Reading is an ability that we practice for a long time before we become good at it. But this practice starts long before we pick up our first book or go to school. Before we are even born, we start listening to sounds and hearing basic parts of language. These experiences shape areas of the brain that later help us to develop reading skills. In 1983, a professor named Jeanne Chall [1] said that learning to read happens in several stages (Figure 1). Today we know that many different factors can affect these reading stages and that learning to read can differ among individual children and across the globe. Such differences exist because many things can affect reading development, like where we grow up, which language we speak, the vocabulary of our language, our ability to play games with speech sounds (e.g., say "banana" without saying the sound/b/), and how good we are at understanding stories [2]. 
MRI

Stands for magnetic resonance imaging. MRI allows scientists to take images of all parts of the human body. It works with strong magnets and radio waves.

\section{NEURON}

Nerve cells within the brain or spinal cord.

\section{AXON}

A part of the nerve cell that can connect with other cells and in this way transport information from one cell to another cell.

\section{WHITE MATTER} TRACT

A collection of many axons connecting different brain areas with each other.

\section{HOW THE BRAIN LEARNS TO READ}

Brain imaging techniques, such as magnetic resonance imaging (MRI) make it possible to study how the brain learns. MRI is like a big camera that can take images of different parts of the body-for instance, the brain. MRI works by measuring signals coming from water molecules in the body. Every single part of the body is a little bit different, and because of that, the MRI signal coming from each part differs a bit, too. Using computers scientists can create detailed images from these signals (if you are interested in reading more about the physics of MRI, you can read "The physics of MRI and how we use it to reveal the mysteries of the mind" written for children by Kathryn Broadhouse [3]). MRI allows us to study both how the brain works while we are doing or feeling something (the brain's function), as well as how the brain is built (its structure).

When the brain grows and learns, connections between different parts of the brain are created. Over time, these connections build networks. Networks are different parts of the brain that work together. Like a well-trained musical group, brain networks help us learn skills like reading. While we learn, the cells of the brain (called neurons) connect to each other by reaching out their tiny arms (called axons) or even by growing new arms. Over time, many axons connect to each other and build long highways, called white matter tracts. These highways allow information to travel from one part of the brain to another. Using MRI, scientists have learned that we can read because different parts of the brain become more active and communicate with each other as we learn. These brain areas have funny-sounding names: occipitotemporal area, or the "letter box" of the brain (where we process letters and words); temporoparietal area (helps us to play with the sounds of our language, such as figuring out that "banana" without the sound /b/ is "anana"); and inferior frontal region (the "captain" that directs us). When brain areas talk with each other often, the highways can become stronger.

An important highway for reading is a collection of axons that we call the arcuate fasciculus, because it is shaped like an arc. Within the network of brain areas that help us to read, paths like the arcuate fasciculus allow the transportation of information from one area to another. In children who struggle with reading, the brain's reading network is sometimes built a bit differently or the information takes other routes. In some brains, the highways transporting the information between the reading areas may be narrow, like having just one lane of traffic instead of two. Or, the highways may be less smooth, like a road with a bumpy surface or many traffic lights. These differences make communication between the brain regions challenging and, in some children, reading becomes a difficult task (Figure 2). 
Figure 2

The reading brain. At the top, you can see the names and functions of brain regions that are used for reading. Together, these brain regions form the brain's reading network. During reading, these areas become more active and talk with each other. Sometimes information transmission in this network goes smoothly (bottom left), but sometimes it can be more challenging (bottom right) (Illustrations: N. M. Raschle).

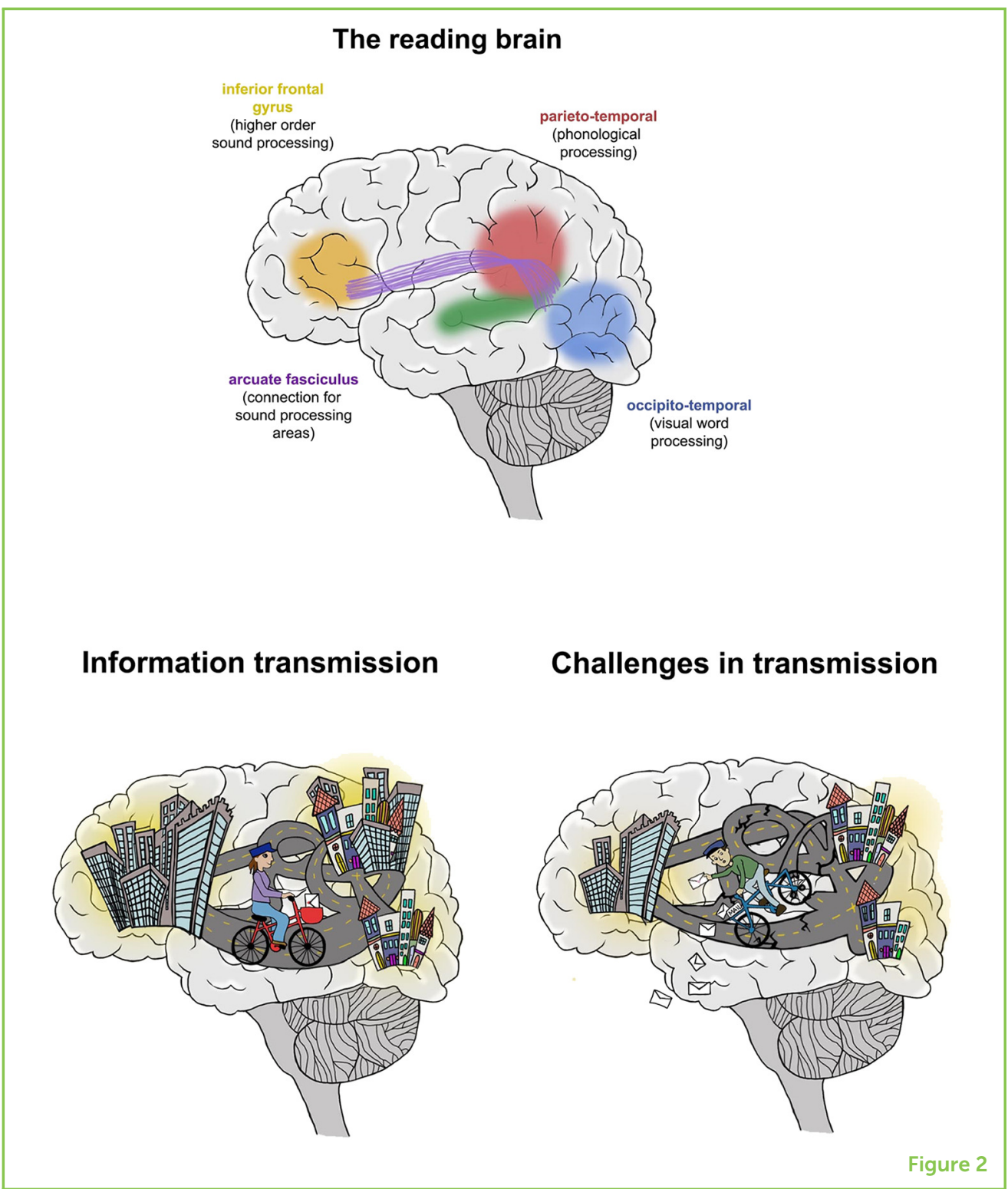

\section{DEVELOPMENTAL DYSLEXIA AND THE DYSLEXIA PARADOX}

The development of the human brain is complex, and it is not surprising that some brains develop differently than others. Sometimes these differences can have consequences that are discovered only much later in life. In a regular school class, about one or two in a class of 20 children find learning to read extremely challenging. Many researchers would like to be able to predict, as early as possible, which children may struggle with reading. It is much easier to help a child when the problems start than to wait and try to help them years later. When we are young, our brains are much more flexible for things like language, and this makes it easier to learn new things and address problems. Also, if help comes very late, some struggling children may become sad, frustrated, or experience bullying and may even stop wanting to learn. Some parents may become impatient and think their 
Figure 3

The dyslexia paradox. In most children, reading problems are not discovered until the second or third grade (green area). However, the best and most effective window for helping them is much earlier (pink area).

\section{DYSLEXIA}

A learning disorder that involves difficulty reading due to problems identifying speech sounds and learning how they relate to letters and words.

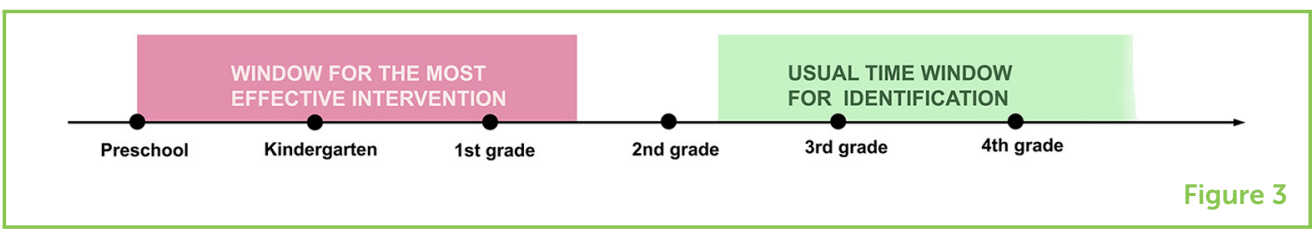

child is not trying hard enough. These are important reasons why scientists want to help identify these children as early as possible.

Some children who have reading difficulties may be diagnosed with developmental dyslexia, which is a type of reading disability. Usually, this diagnosis is made after the children have been trying to learn to read for quite some time (like in second or third grade). The struggle to read has nothing to do with missed practice, laziness, or lack of trying. However, by this time, children need to catch up quite a bit to do well in school, which is a big challenge. As mentioned before, research has shown that the best time to help children with reading is in kindergarten or first grade, when the brain is a lot more moldable. The difference between when we identify children who struggle with reading and when they could best be helped is called the dyslexia paradox, because it is something that contradicts itself (Figure 3).

Scientists have shown that we can detect early signs of reading difficulties through spoken, written, or computer tests. We were curious to know whether MRI could also be used to detect early differences in the brains of children who would ultimately have difficulty reading. We found that young children who later struggle with learning to read seem to have a different reading network [4-6]. But, with support and the right teaching, this can be changed.

\section{THE MAGIC OF HELPING OTHERS}

Unlike the wizards in Harry Potter, scientists cannot read people's minds or use any other forms of magic. But we have come up with various methods and technologies to study the learning brain, one of which is MRI. MRI has allowed scientists to study the parts of the brain that enable us to read and has shown us what might be happening in the brains of children who struggle with reading. With each study, scientists learn more about how we learn and why it is harder for some people to learn than it is for others. Eventually, this information may help us to support each child to reach his or her goals. And being able to do so is true magic.

\section{ACKNOWLEDGMENTS}

We would like to thank those who assisted in the translation of the articles in this Collection to make them more accessible to kids 
outside English-speaking countries, and for the Jacobs Foundation for providing the funds necessary to translate the articles. For this article, we would especially like to thank Nienke van Atteveldt and Sabine Peters for the Dutch translation. We would like to say thank you and dedicate this article to all children who are or were struggling with learning to read as well as the educators, parents and professionals who help them.

\section{REFERENCES}

1. Chall, J. S. 1983. Stages of Reading Development. New York, NY: McGraw-Hill Book Company.

2. Castles, A., Rastle, K., and Nation, K. 2018. Ending the reading wars: Reading acquisition from novice to expert. Psychol. Sci. Public Interest. 19:5-51. doi: $10.1177 / 1529100618772271$

3. Broadhouse, K. 2019. The physics of MRI and how we use it to reveal the mysteries of the mind. Front. Young Minds 7:23. doi: 10.3389/frym.2019.00023

4. Raschle, N. M., Zuk, J., and Gaab, N. 2012. Functional characteristics of developmental dyslexia in left-hemispheric posterior brain regions predate reading onset. Proc. Natl. Acad. Sci. U.S.A. 109:2156-61. doi: 10.1073/pnas.1107721109

5. Raschle, N. M., Chang, M., and Gaab, N. 2011. Structural brain alterations associated with dyslexia predate reading onset. Neuroimage 57:742-9. doi: 10.1016/j.neuroimage.2010.09.055

6. Langer, N., Peysakhovich, B., Zuk, J., Drottar, M., Sliva, D., Smith, S., et al. 2017. White matter alterations in infants at risk for developmental dyslexia. Cereb. Cortex 27:1027-36. doi: 10.1093/cercor/bhv281

SUBMITTED: 31 October 2019; ACCEPTED: 01 May 2020; PUBLISHED ONLINE: 11 June 2020.

EDITED BY: Stephan E. Vogel, University of Graz, Austria

CITATION: Raschle NM, Borbás R, King C and Gaab N (2020) The Magical Art of Magnetic Resonance Imaging to Study the Reading Brain. Front. Young Minds 8:72. doi: 10.3389/frym.2020.00072

CONFLICT OF INTEREST: The authors declare that the research was conducted in the absence of any commercial or financial relationships that could be construed as a potential conflict of interest.

COPYRIGHT () 2020 Raschle, Borbás, King and Gaab. This is an open-access article distributed under the terms of the Creative Commons Attribution License (CC BY). The use, distribution or reproduction in other forums is permitted, provided the original author(s) and the copyright owner(s) are credited and that the original publication in this journal is cited, in accordance with accepted academic practice. No use, distribution or reproduction is permitted which does not comply with these terms. 

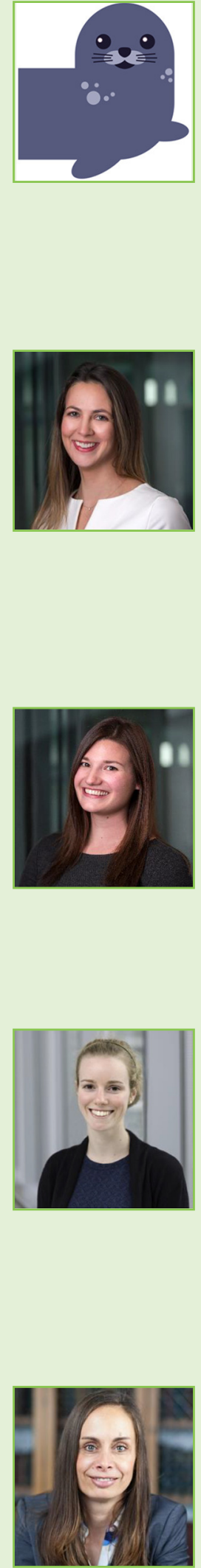

\section{YOUNG REVIEWERS}

\section{CASCADIA ELEMENTARY, AGES: 8-9}

Our class is the Harbor Seals! We are a group of third grade kids who love reading and math. We have 9 girls and 14 boys in our class. We are an energetic bunch who love discussing our ideas together and learning about new things. We have been focusing a lot on collaboration, speaking, and listening to each other this year and we are so excited to be a part of the Frontiers community!

\section{AUTHORS}

\section{NORA MARIA RASCHLE}

Nora is an Assistant Professor of Psychology at the Jacobs Center for Productive Youth Development at the University of Zurich in Switzerland. Her team at the NMR Kids Lab is interested in knowing more about how the human brain grows, changes, and learns. Nora also loves to draw science cartoons and believes that knowledge can be taught in a way that is fun and understandable for all. She likes to try out new things with her three kids, like baking a giant cake, singing karaoke songs even though she is a horrible singer, building stuff (like robots), or visiting exciting places. *nora.raschle@jacobscenter.uzh.ch

\section{RÉKA BORBÁS}

Réka is a doctoral student in Neuropsychology at the Jacobs Center for Productive Youth Development at the University of Zurich in Switzerland. She is working with families and is super interested in how kids and their parents' brains work. For this, she is preparing families to go inside an MRI scanner to take a peek at their brains. Within the NMR Kids Lab, she tries to make research fun for everyone and is developing exciting games to play in the scanner. In her free time, she enjoys playing board games, snuggling with her furry cat, and baking for her friends and family.

\section{CAROLYN KING}

Carolyn is a Research Assistant at the Laboratories of Cognitive Neuroscience at Boston Children's Hospital and Harvard Medical School. She works with kids every day to understand how some kids learn to read and do math differently than others. She spends a lot of her time playing thinking games with preschoolers and kindergarteners, and she also gets to travel across the United States to test out new games. Carolyn loves to hike the tallest mountains she can find and play with alpacas, bunnies, and cats at her grandmother's alpaca farm. One of the alpacas has even hiked a mountain, and Carolyn hopes to day hike with him!

\section{NADINE GAAB}

Nadine is a professor at Boston Children's Hospital and the Harvard Medical School. Her usual work week includes looking at children's brains, chatting with her students, teaching a class, sitting in boring meetings, or playing with kids who come to the lab. She also travels to (mostly cool) places and tells people about dyslexia, reading development, and the brain. In her free time, she likes to play board games with her three children and enjoys watching her daughter play soccer and her son play baseball. She loves seafood and chocolate ice cream. When she grows up, she would like to become a chef. 